\title{
Reply to the Letter: " $N$-Butyl Cyanoacrylate Glue: The Best Hemostatic Embolic Agent for Patients with Acute Arterial Bleeding"
}

\author{
Umut Ozyer $^{1}$ (D)
}

Received: 22 April 2017/ Accepted: 28 April 2017/Published online: 11 May 2017

(C) Springer Science+Business Media New York and the Cardiovascular and Interventional Radiological Society of Europe (CIRSE) 2017

\section{To the Editor,}

I read the letter: " $N$-butyl cyanoacrylate glue: the best hemostatic embolic agent for patients with acute arterial bleeding." First of all, I am grateful for their remarks and I have two comments to make.

Firstly, the authors recommended skipping conservative management in case of arterial extravasation on CT scan. They prefer treating these patients with primary transarterial embolization. I definitely agree with this recommendation. My experience suggests that clinicians should be encouraged to refer the patients with a suspicion of active bleeding to the interventionalist as soon as possible, preferably during acquisition of the CT scan. Thus, interventionalist can evaluate the CT scan, consult with the clinician and transfer the patient to the angiography suite to gain time. Otherwise, precious time is lost waiting for the diagnosis of active bleeding and several consultations to be done. Furthermore, when the interventionalist is uninformed about the patient, clinicians might prefer conservative management primarily and refer the patient after a large hematoma develops.

Secondly, I have an objection to the authors' proposal that only the use of authorized glues should be the rule and Onyx ${ }^{\circledR}$ should be used instead of Histoacryl ${ }^{\circledR}$. I believe this is arguable in lack of availability of Trufill ${ }^{\circledR}$ or Glubran $2^{\circledR}$. After adjusting the polymerization time with oily radiopaque in 1982 , Histoacryl ${ }^{\circledR}$ has been increasingly used in daily practice and in various embolization procedures [1]. Thus, I do not accept authors' remarks about off-label use.

Umut Ozyer

umutozyer@gmail.com

1 Department of Radiology, Faculty of Medicine, Baskent University, 06490 Bahçelievler, Ankara, Turkey
As in the case of Histoacryl ${ }^{\circledR}$, agent not released for a special purpose can be used if this is common sense supported by the literature, at least in many countries [2]. On the other hand, almost all literature on Onyx ${ }^{\circledR}$ focuses on neurologic interventions and aortic endoleak treatment. There is no randomized controlled trial for treatment of non-neurological bleeding, and case series are few. These few studies mainly concern gastrointestinal and pulmonary bleeding and reported Onyx ${ }^{\circledR}$ use for spontaneous hematomas is limited to 20 cases [3]. Furthermore, preparation time of 15-20 min of Onyx ${ }^{\circledR}$-dimethylsulfoxide mixture, requirement of slow injection and vasospasm in case of fast injection limit its use in life-threatening hemorrhage. High costs of Onyx ${ }^{\circledR}$ and injection catheters are the other limiting factors. Although Onyx ${ }^{\circledR}$ seems effective, I still suggest embolization with Histoacryl ${ }^{\circledR}$ in lack of authorized glues.

Compliance with Ethical Standards

Conflict of interest The author declares that he has no conflict of interest.

\section{References}

1. Stoesslein F, Ditscherlein G, Romaniuk PA. Experimental studies on new liquid embolization mixtures (histoacryl-lipiodol, histoacryl-panthopaque). Cardiovasc Intervent Radiol. 1982;5(5): 264-7.

2. Ozyer U. Transcatheter arterial embolization with $N$-butyl-2cyanoacrylate in the management of spontaneous hematomas. Cardiovasc Intervent Radiol. 2017;40:41-9.

3. Kolber MK, Shukla PA, Kumar A, Silberzweig JE. Ethylene vinyl alcohol copolymer (Onyx) embolization for acute hemorrhage: A systematic review of peripheral applications. J Vasc Interv Radiol. 2015;26:809-15. 